Письменные памятники Востока, 2021, том 18, № 1 (вып. 44), с. 74-83

\title{
Who Was Collecting Hebrew Books \\ in the Capital of Russian Empire and Why
}

\author{
С.М. Якерсон \\ Институт восточных рукописей РАН
}

DOI: 10.17816/WMO63141

К началу XX в. в столице Российской империи сформировалось уникальное собрание еврейских рукописей (более 20000 единиц хранения) и первопечатных книг. Эти рукописи и книги оказались в С.-Петербурге в составе нескольких частных коллекций, таких как коллекция протестантского библеиста и палеографа Константина фон Тишендорфа, караимского духовного лидера Авраама Фирковича, архимандрита Антонина, баронов Гинцбургов, купца Первой гильдии Моше Арье Лейба Фридланда и профессора-востоковеда Даниила Хвольсона. Истории формирования этих коллекций и мотивам собирательской деятельности их владельцев посвящена данная статья.

Ключевые слова: еврейские рукописи, еврейские инкунабулы, Российская национальная библиотека, Российская государственная библиотека, Институт восточных рукописей РАН, Константин фон Тишендорф, Авраам Фиркович, архимандрит Антонин, Давид Гинцбург, Даниил Хвольсон, Моше Фридланд.

Статья поступила в редакцию 18.10.2020.

Якерсон Семен Мордухович, доктор исторических наук, ведущий научный сотрудник Отдела Ближнего и Среднего Востока ИВР РАН, РФ; 191186 г. Санкт-Петербург, Дворцовая набережная, 18 (shiakerson@yandex.ru).

() Якерсон С.М., 2020

Up to the February Revolution of 1917, St. Petersburg — the capital of Russian Empire - was virtually inaccessible to the Jewish population. Nevertheless, it was St. Petersburg, of all places, that in the late 19th - early 20th centuries turned into the most important international center of accumulating medieval Hebrew manuscripts and incunabula. It is here, in this city, that the vast majority of the most ancient dated Hebrew manuscripts of the 10th-11th centuries have ended up, along with thousands of manuscripts of the late Middle Ages and the early modern period, and unique collections of Hebrew 74 incunabula. 
It is hard to overrate the significance of the St. Petersburg collection of Hebrew manuscripts for contemporary scholarship. To illustrate the point, let me cite the figures related to just one academic discipline - Hebrew codicology. Here we have the earliest dated Hebrew manuscript (the so-called Codex Babylonicus Former Prophets, with Babylonian vocalization. Sine loco 916 C.E.); the earliest dated manuscripts from Palestine (988/9 C.E.), from the regions of Syria and Lebanon (1091 C.E.), Egypt (1008-13 C.E.), Yemen (1144 C.E.), Spain (1119 C.E.), Tunisia (941-1039? C.E.), Byzantium (1027 C.E.) and others; the earliest dated paper manuscript (1006 C.E.), the earliest dated paper manuscripts from Spain (1119 C.E.), Italy (1276/7-1284/5 C.E.) and North Africa (1124/6 C.E.); the earliest dated manuscript copied by several scribes; the earliest dated manuscript of the Pentateuch (929 C.E.) and the complete Bible (Codex Petropolitanus, Fustat, 100813 C.E.); the earliest manuscript made for public use (1363 C.E.), the earliest dated manuscript with numbered quires and custods; the earliest Eastern manuscript copied by scribes from the Maghreb states, Spain etc. ${ }^{1}$ Perhaps, one of the best illustrations of academic importance of the Russian collections is the collection of the Russian National Library (RNL) and, particularly, the first volume of the Master Catalogue of Dated Hebrew Manuscripts (Codices), published in 1997. The volume contains a detailed paleographic description of manuscripts copied before 1020: all five of the preserved dated odices and six out of ten manuscript fragments belong to the RNL collection in St. Petersburg.

All these treasures of the Jewish culture were created outside the Russian borders more precisely, in the Middle East and Western Europe - and could not have been viewed as items directly related to the history of the Russian Jewry were it not for the fact that all of them, due to various historical circumstances and thanks to particular collectors, made it to the shelves of St. Petersburg libraries. The article attempts to analyze the motivation behind the collectors' efforts as it could be traced based on the chronological development of specific collections. Since the current format would not allow us to list the names of all collectors, let us highlight those whose contributions proved to be the most crucial for what we now know as St. Petersburg collections of Hebrew books.

The first collector on my list is a prominent Protestant paleographer and Biblical scholar Konstantin von Tischendorf. His collection arrived at the "Manuscript Depot" of the Imperial Public Library (now RNL) in St. Petersburg in 1858-1859 and contained 59 manuscripts.

Konstantin von Tischendorf (1815-1874) - a theologian, Biblical scholar, paleographer and expert in classical languages - has never lived in Russia, yet he belonged to that remarkable array of the Germans who played a vital part in the development of Russian culture and sciences in the second half of the 19th century. In 1869, Tischendorf was granted hereditary Russian nobility. It is possible to conclude that his major scholarly ambition was to prepare a critical edition of the Greek Bible (particularly, the New Testament) based on ancient manuscripts that had yet to be uncovered over the course of the project.

In view of that goal, Tischendorf launched three expeditions to the Middle East in 184344, 1853 and 1859. His third expedition had to do with Russia directly: it was funded by Emperor Alexander II and conducted under his patronage. The expedition resulted in uncovering the oldest codex of the Greek Bible - the so-called Codex Sinaiticus, tentatively dated to the mid-4th century C.E. — at the Saint-Catherine Monastery on the Sinai Peninsula.

\footnotetext{
${ }^{1}$ On the significance of the Russian collections of Hebrew manuscripts for codicology, see: Beit-Arié 1991; Idem 1998.
} 
With Konstantin von Tischendorf as an intermediary, the manuscript was presented to Emperor Alexander II as a gift from the Sinai Monastery. This event has ignited public interest to all matters Biblical and particularly to searches and acquisitions of Biblical rarities. From 1869 to 1933, the Sinai Codex was housed at the RNL. In 1933, the Soviet Government sold it to the British Museum in London. Today it is stored at the British Library. During his Middle East expeditions, Tischendorf has been collecting various materials, and among his findings there were the 59 Hebrew manuscripts mentioned above.

What moved Tischendorf to become a collector? First and foremost, he was undoubtedly driven by his professional interest as a paleographer and Biblical scholar. To be sure, Hebrew manuscripts were not his major focus, but they fitted nicely into his general collecting agenda: the Bible, the Middle East and the materials required for a critical edition of the Biblical text.

It is necessary to note that the Library's acquisition of the Tischendorf collection, and specifically of the Sinai Codex, had influenced the Emperor's decision to purchase yet another collection of Hebrew manuscripts, the one that subsequently made the Library a world-famous and the most esteemed storage of ancient Hebrew manuscripts. The collection in question has been amassed by the next protagonist of this story, an outstanding Karaite gakham (sage) Avraam Firkovich.

Today we have a considerable number of works about Avraam Firkovich, and his name is familiar to every student of Medieval Studies (see, e.g., Vikhnovich 2012, Iakerson 2008: 20-43). He was born in 1787 in the town of Lutzk, Volhynia (today's Ukraine) and died in 1874 in Chufut-Kale, Crimea. It would not be wrong to say that Firkovich was the most controversial figure in the history of Hebrew manuscript collections. Yet, it is to him that we owe the largest private collection of Hebrew manuscripts with the highest percentage of rarities.

Avraam Firkovich was definitely born with a "collector's gene": according to his own words, he started collecting manuscripts at a fairly early age. Be that as it may, what we are certain about is that, by 1820 , when he and his family were moving from Lutzk, Volhynia, to Crimea, his luggage already included some boxes with manuscripts. We also know that he was purchasing manuscripts while making a pilgrimage to the Holy Land in 1830-31 and staying in Constantinople in 1831-32.

Speaking of his remarkable set that is today known among scholars as the First Firkovich Collection we, however, have to emphasize that his reason for building this collection was purely ideological, sprung from the historical realities of the Russian Empire. Thus, it is impossible to tell the story of his collections without giving a brief overview of the "historical landscape" of his time.

The reign of Catherine the Great was marked by a substantial territorial expansion. As a consequence, the Jews residing in the newly acquired lands became subjects of the Russian Empire. Three partitions of Poland (in 1772, 1793 and 1795) and the annexation of Crimea in 1783 turned the Russian Empire, a state that Jews were not allowed to enter, into a country with the largest Jewish population in the world.

Part of this unexpectedly acquired Jewish civilization was a small group of Karaite Jews with communities in Crimea (Solkhat, Chufut-Kale, Mangup, Kezlev, Kaffa, Yevpatoria), Lithuania (Troki, Vilna), Galicia (Galich) and Volhynia (Lutzk). Having become Russian subjects, the Karaites attempted to disassociate themselves from the majority of Rabbinical Jews (also known as the Rabbinites) and applied for a legal status that would keep them out of reach of anti-Jewish laws. The Karaite community was moving along towards that goal 
rather well: as early as in 1795, Catherine the Great exempted Karaites from the discriminatory double tax imposed on the Jewish population and granted them the right to purchase land; and in 1827, her grandson, Nicholas I, released them from the worst nightmare of the Jewish communities in Russia — mandatory military service.

The legislative machine in Russia was slow, but eventually the time has come when the status of the "Biblical nation" had to be defined: on January $31^{\text {st }}, 1839$, the Karaite Ecclesiastical Administration in Yevpatoria received a formal inquiry from the Odessa Society for History and Antiquities on the genealogy of the Karaites. The inquiry was a serious matter, since the future of the Crimean Karaites literally depended on their answers. Would they enjoy all the civic rights of the native population of the vast Russian Empire, or would they be turned into pariahs and outcasts, just like their "Rabbinite brothers"? The inquiry contained six questions that came to be known as "The Six Questions to Karaites":

(1) What nation do the Karaites belong to and where do they come from?

(2) When did they arrive in Crimea and why?

(3) What are their distinctive qualities and characteristics, and what are their occupations?

(4) Have they had among them (and do they have now) famous men who glorified their names in history with their outstanding good deeds?

(5) Do they have at their disposal books of historical narratives and truthful documents inherited from their forefathers that could prove the antiquity of their religion and faith?

(6) When and why have they separated from the Rabbinite Jews, and what are the differences between them in the matters of faith?

At that point, the Karaites had no answers to these questions, and it was none other than Firkovich who took it upon himself to locate the wanted data in the aforementioned old books "of historical narratives and truthful documents." Over the period from January 1839 to February 1840, he visited the North Caucasus and emptied all Genizahs ${ }^{3}$ in Crimea. Striving to get the much-needed proofs, he would change the dates and forge names and other details in the manuscripts he had found. This story, however, is widely known, so we will not dwell on it here (See, e.g., Harkavy and Strack 1875; Shapira 2004; Iakerson 2008: 31-36). In 1862, the Firkovich collection was purchased by Alexander II for the Imperial Public Library.

Firkovich's findings helped "reconstruct" the history of Karaites as an ancient Biblical nation that had resided in Crimean lands from times immemorial and had nothing to do either with the sad end of the Son of God's earthly life or with the subsequent distortion of the Biblical laws by the Talmudic rules. Based on these arguments, all legal restrictions for the Karaites were lifted and in 1863 they received equal civic rights with the native population of Russia.

In 1899, the Imperial Public Library received a book collection of the Chief of the Russian Ecclesiastical Mission in the Holy Land, Archimandrite Antonin (Andrey Ivanovich Kapustin, 1817-1894), according to his will. A Renaissance man - a theologian, an astronomer, a Byzantologist, a numismatist and archeologist, a poet and an artist - Archimandrite Antonin has strengthen the Jerusalem Mission and significantly increased its land

\footnotetext{
${ }^{2}$ Transl. from Hebrew. For Hebrew see: Firkovich 1872: 8.

${ }^{3}$ Genizah (Heb. "concealment", "archive") - 1. Storage for unusable Jewish books and documents containing the name of God or his attributes; 2. Storage for any materials written in Hebrew characters. Uncovering of Genizahs played an invaluable part in promoting modern Jewish Studies.
} 
property. His book collection reflected his theological interests and contained materials in both European and Oriental languages. One of the sections of Antonin's library was a collection of fragments of Hebrew manuscripts.

He had been building his library over decades, but the Hebrew part was, most probably, of a different nature. His Hebrew collection includes 1178 fragments whose content, chronology and physical state strongly resemble those uncovered in the Cairo Genizah ${ }^{4}$ and clearly have a similar origin. Sadly, we do not know the exact circumstances of Antonin's acquisition of this collection. However, judging from its composition and the overall quality of its materials, it is reasonable to assume that Archimandrite purchased the whole corpus of these Middle Eastern manuscripts in one bulk, while being in Palestine.

What was it that motivated Antonin to collect Hebrew manuscripts? Perhaps we should seek the answer in the general policies of the Czarist government in the East and, particularly, in the Holy Land. As early as in 1844, the first Director of the Asiatic Museum, Academician Christian Danilovich Frähn, successfully lobbied an official directive (in force up to the First World War) requiring that Russian Consuls stationed in the East build manuscript collections. It stands to reason, however, that this governmental initiative concerned not only Russian diplomatic missions abroad, but also Ecclesiastical ones, especially in the areas where official diplomatic presence of the Russian Empire was lacking or "weak", as was the case in Palestine. If so, Antonin would have had a legitimate pretext to conduct his collecting projects, and even if not, the political initiative of the state must have encouraged and inspired him as a collector.

In the second half of the 19th century, a permanent Jewish community began gradually developing in the capital of the Empire. Initially, it consisted of the so-called "Nicholas's soldiers" - the Jews who completed the whole term serving in the military and thus acquired the right to reside outside of the Pale of Settlement. During the reign of Alexander II, the capital community was not only growing in numbers, but was also changing its composition: in the last third of the century, there was already a substantial stratum of welleducated and financially independent $\mathrm{Jews}^{5}$ among whom we see connoisseurs of Jewish culture, Hebrew scholars and Judaica collectors. Below is a brief discussion of the most notable representatives of the latter.

1. Barons Günzburg of Hesse-Darmstadt. The Günzburgs played an exceptional role in the history of the Russian Jewry from the mid-19th century to the beginning of the 20th. Three generations of the Günzburgs took part in developing their famous family library: Osip (Joseph) Gavrilovich (1812-1878), his second son Goratsiy (Horace) Osipovich (1833-1909) and his grandson David Goratsievich (1857-1910). Initially, their library was located in Kamianets-Podilskyi (in today's Ukraine), then - starting from the $1850 \mathrm{~s}$ - the headquarters of the collecting project moved to Paris, where Goratsiy Günzburg resided most of his life. Since 1856, Shneur Sachs (1816-1892), a skilled bibliographer and an expert in medieval Jewish philosophy, was in charge of the project. He recruited many important booksellers to run searches for Hebrew manuscripts and rare incunabula. Thanks to Sachs's efforts and almost unlimited financial resources of the Günzburgs, the collection has rapidly turned into one of the most sizable, or possibly the most sizable, private collection in Europe. Sachs has prepared a hand-written catalogue of a part of the Günzburg col-

\footnotetext{
${ }^{4}$ The Cairo Genizah is the most well-known one. It was uncovered in the late 19th century, in "BenEzra" synagogue in Old Cairo (Al-Fustat). It contained over 200 thousand manuscripts (mainly fragments), most of them from 11 th-14th centuries.

${ }^{5}$ For more on the Jewish community of St. Petersburg, see: Gessen 2005.
} 
lection - Bet Yosef (Hebrew בית יוסף; The House of Joseph), with a brief description of 830 manuscripts. Yet, the chief creator of the collection was undoubtedly David Günzburg. The only member of the family to have received an academic training, he became a specialist in Oriental Studies and Semitic Studies. He studied in St. Petersburg, Paris and Greifswald, researched Judeo-Arabic literature, published great works of medieval Hebrew literature, in particular, decorated books (Günzburg, Stasoff 1905), promoted scholarly Jewish activities, etc. In the $1880 \mathrm{~s}$, he initiated the transfer of his family library to St. Petersburg and since then it became the largest private collection of Hebrew manuscripts in the Russian Empire. Baron David Günzburg passed away unexpectedly in 1910. By then, the library contained approximately 2056 Hebrew manuscripts, about 1000 Arabic manuscripts, 8000 printed books in Hebrew and about 3000 printed books in European languages. During the Russian Civil War, the Günzburg collection - after some adventures on the way - was finally delivered to the Rumyantsev's Museum in Moscow (now RNL), where it is kept to this very day. ${ }^{6}$ Many of these books still carry the ex-libris of the collection: the coat of arms of the Günzburg family and their motto - a verse from the Song of Songs (4:7): Kulakh yafa ra'yati u-mum 'ein bakh (Hebrew כלך יפה רעיתי ומום אין בך; Thou art all fair, my love; there is no spot in thee). ${ }^{7}$

2. Honorary citizen, the First Guild merchant Moses Aryeh Leib (Lev Faivelevich) Friedland (1826-1899). Friedland has amassed a unique collection of printed Hebrew books of the 15th-18th centuries and a very important collection of manuscripts. In 1892, he presented his collection to the Asian Museum of the Imperial Academy of Sciences (today the Institute of Oriental Manuscripts of the Russian Academy of Sciences). His decision was perceived as highly controversial by the Jewish public and caused passionate debates in the Jewish media. Friedland, however, had his reasons which he explained in detail in his letter to Rabbi David Friedman (written on February 22, 1892). ${ }^{8}$ His concerns could be summarized as follows:

(a) Alas, Jewish organizations are not ready to accept my library. Jews have no respect for books nowadays. All my attempts to present small collections to various communities have failed. The books would just stay unpacked for years.

(b) No community is prepared to accept my library in full. Some were willing to take only Rabbinite literature but wanted none of the Karaite corpus, or of the books published by the proponents of the Haskalah (Jewish Enlightenment), and vice versa.

(c) My family has paid a high price for the right to live outside the Pale of Settlement. My children received European education and lost their interest in Jewish books and Jewish culture altogether. My grandchildren have no knowledge of the Hebrew tongue whatsoever.

(d) It is my wish that the collection be preserved as a whole, as a single, indivisible holding and that its printed catalogue be published. Today, only the Asian Museum has sufficient resources to fulfill my wish.

(e) I am looking into the future and do believe that the shameful limitations prescribing my people to reside exclusively within the Pale of Settlement will be lifted and the Jews will be able to settle in St. Petersburg as free and full-fledged citizens. Then they will get a chance to enjoy my collection in full.

\footnotetext{
${ }^{6}$ For more on the Günzburg collection, see: Lisitsina 2010.

${ }^{7}$ The ex-libris can also be found in Vereshchagin's albums (Vereshchagin 1902: pic. 41) and Ivask's albums (Ivask 1905: 105-106, pic. 105).

${ }^{8}$ For the complete text of the letter in Russian, see: Iakerson 2008: 53-55.
} 
Before Friedland gave his collection over to the Asiatic Museum in the end of the 19th century and the Günzburg collection headed to Moscow in the beginning of the 20th century, they had been part of St. Petersburg's Jewish cultural landscape for decades. Even though they were kept in their owners' private houses, scholars and researchers could come and work with them.

Here is what an outstanding Jewish historian Semyon Dubnov writes in his Book of Life: "I've been spending a lot of time working in the rich book-storage of the merchant L. Friedland on the Vasilyevsky Island"; " "Back in the day I am talking about, the library was still kept in Friedland's apartment" (Dubnov 2004: 159); and another excerpt: "I remember those two sunny days in late February that (I spent) in the luxurious office of Günzburg's house on Konnogvardeysky Boulevard. ${ }^{10}$ I was feverishly copying the precious catalogue entries [...] The materials I found in St. Petersburg opened up new paths for my research..." (Dubnov 2004: 159).

Friedland's reasons for collecting Hebrew books and manuscripts were also explained by Dubnov in the aforementioned book: “...it was he [viz. the bibliographer Samuel Wiener] who persuaded one rich St. Petersburg merchant, who was comfortless after the passing of his wife, to erect for her a monument in the shape of a book-storage that would host all Hebrew books ever printed as well as Hebrew manuscripts. Via Wiener, the widower had been purchasing whole libraries and manuscript collections and then, also following Wiener's suggestion, bequeathed them all to the Russian Academy of Sciences, to be placed in its Oriental Department, that is the Asiatic Museum, under the condition that Wiener is assigned to the position of librarian. This position allowed the provincial bibliographer to obtain the right to settle in St. Petersburg for the duration of his work on a detailed catalogue of the Biblioteca Friedlandiana, then newly-arrived at the Academy. Wiener stretched his term: his work on the 'Koheleth Moshe' Catalogue ${ }^{11}$ lasted thirty years (over the course of which less than half of it was published in installments). Meanwhile, Wiener's temporary residence permission turned into a permanent one. So, in a way, it is because of the Pale of Settlement that the monumental Catalogue of Hebrew letters of all times has never been brought to completion..." (Dubnov 2004: 158-59).

Dubnov's account is widely considered to be accurate. I claim, however, that it is highly unlikely that this narrative reflects the true course of events. Lev Friedland's wife, Keyla, passed away in 1888. The collection had doubtless been started long before that, so probably the best we can do is believe the reason cited by the collector himself. Initially, he was driven by his genealogy research: the Friedland family was not only well-off, but also wellbred, tracing its line back to the so called Ruzhan martyrs. ${ }^{12}$ Samuel Wiener did not have any reasons to deliberately slow down the cataloguing project, since in 1899, upon the petition of the Academy, Emperor Nicholas II actually granted him honorary citizenship a status that presupposed the right to reside in the capital city. Be that as it may, as far as the collection proper is concerned, it was a library rather typical for a very rich Jew with an interest in books.

${ }^{9}$ Friedland lived in his own house on Vasilyevsky Island, 3rd Lane, 48 (Dubnov 2004: 158).

${ }^{10}$ Baron David Günzburg lived in his own house on Konnogvardeysky Boulevard, 17.

${ }^{11}$ The Catalogue in question is the famous catalogue of Friedland's collection (Wiener 1893-1918).

${ }^{12}$ In 1657, on the eve of Passover, a corpse of a Christian boy was found in the Jewish neighborhood of Ruzhany (Belarus). The Jews were accused of ritual murder and the community leaders - Israel ben Shalov and Toviah ben Joseph - were executed. Friedland's genealogy research was published by I.T. Eisenstadt in 1897-1898 (Eisenstadt 1897). 
The Günzburg collection was far more complex in its composition, being impacted by the professional interests of David Günzburg in the field of Oriental Studies. Thus, the collection contained both books in Jewish languages and European books on Jewish Studies and Semitic Studies. In other words, we can describe the Günzburg library as a classic library of educated European Jews.

Professor Daniel Abramovich Chwolson (1819-1911) is yet another type of a Jewish collector, and his case is a peculiar one. Born into a poor Jewish family in Vilna, Chwolson received a traditional Jewish upbringing. Much later in life, he becomes fascinated with the ideas of the Jewish Enlightenment (the Haskalah) and embarks on his journey abroad, "in search of knowledge". He studies in Breslau (now Wroclaw), defends his dissertation in Leipzig and in early 1850s returns to Russia. With his European education in Semitic Studies, he could have expected a brilliant academic career, if it were not for one obstacle his Jewish faith. He decides to convert to Christianity. Upon conversion, Chwolson becomes the Chair in Hebrew, Syrian and Chaldean Philology with the Oriental Department of the Saint-Petersburg University and teaches Semitic languages in a number of other educational institutions. The rest of his years Daniel Chwolson spends as an active and prolific scholar and - which is quite unusual for a baptized Jew, as an active and positive participant in the life of the Jewish community of St. Petersburg and Russian Jewry in general. Chwolson's case is truly beyond the ordinary: on the one hand, we do not have any other Jewish scholars (specifically in the field of Judaica) of such magnitude who would opt for such a serious moral compromise; on the other hand, we do not know any other examples when a renegade Jew would continue being such a passionate defender of the desecrated faith and its loyal adepts. He writes for the Jewish press on the problems of Jewish education and publishes scholarly works exposing common anti-Semitic myths. ${ }^{13}$ Among Chwolson's academic interests were Jewish paleography and the history of Hebrew print. In 1897, he published a catalogue of the Jewish segment of his library (Chwolson, 1897) that contained descriptions of 20 manuscripts and 2208 books (including 33 incunabula!). It is worth noting that his is a unique case: no other Jewish collector has compiled a catalogue of his own library. Chwolson's catalogue testifies to his profound expertise in bibliography. His library was purchased by the Asian Museum in 1910, not long before the collector's death. The collection of Daniel Chwolson is undoubtedly one of a professional Semiticist. Yet, one cannot help feeling that the Jewish segment of his library was there not for mere academic purposes: Chwolson seems to have been driven by a certain "collecting gene" and his efforts were colored by a certain national "sentiment".

To sum up our analysis of the motivations for collecting Hebrew books in the capital of Russian Empire, we see a whole range of various reasons: scholarly or state interests, political or religious ambitions, collecting for its own sake, etc. The social composition of the collectors whose libraries are now special pride of the Russian book holdings, is no less remarkable: a Protestant Biblical scholar, a Karaite public activist, an Orthodox Christian Archimandrite, a Jewish baron, a First Guild Merchant, a renegade Jew. It is thanks to them all that today the libraries of St. Petersburg and Moscow have approximately 24 thousand Hebrew manuscripts, 86 Hebrew incunabula, copies of almost every known Hebrew paleotype, and virtually innumerable Hebrew books published from the second half of the 16 th century to the second half of the 19th century.

\footnotetext{
${ }^{13}$ See, e.g., Chwolson's renowned book On Some Medieval Accusations against the Jews (Chwolson 2010).
} 


\section{References}

Beit-Arié, Malachi. "Hebrew Manuscript collections in Leningrad and their importance to the History of the Hebrew Book". Jewish Studies. Forum of the World Union of Jewish Studies. 31, 1991, pp. 33-46 (in English).

Beit-Arié, Malachi. "The Accessibility of the Russian Manuscript Collections: New Perspectives for Jewish Studies". Jewish Studies in a New Europe: Proceeding of the Fifth Congress of Jewish Studies in Copenhagen 1994. Copenhagen, 1998, pp. 82-98 (in English).

Chwolson, Daniel. Chwolson Catalog der Hebräischen Bücher... Wilna, 1897 (in Hebrew).

Chwolson, Daniel. Chwolson, O nekotorykh sredneverovykh obvineniiakh protiv ievreev [On Some Medieval Accusations against the Jews]. Moscow, 2010 (in Russian).

Codices hebraicis litteris exarati quo tempore scripti fuerint exhibentes. Tome I. Jusqu'à 1020. Malachi Beit-Arié, Colette Sirat, Mordechai Glazer avec la collaboration de Tamar Leiter, Shimon Iakerson, Michele Dukan, Edna Engel, Monique Zerdoun Bat-Yehouda. Brepols (Monumenta Palaeographica Medii Aevi... Series Hebraica), 1997 (multilingual).

Dubnov, Semen. Kniga zhizni. Materialy dlia istorii moiego vremeni. Vospominaniia i razmyshleniia [The book of life. Materials for the history of my time. Memories and Reflections]. Moscow, 2004 (in Russian).

Firkovich, Abraham. Sefer Avne-Zikkaron. Sbornik nadgrobnykh ievreiskikh nadpisei na Krymskom poluostrove [Memorial stones. Collection of gravestone Jewish inscriptions on the Crimean peninsula]. Wilna, 1872 (in Russian).

Gerd, Lora. "Archimandrit Antonin Kapustin i iego nauchnaia deiatelnost'. Po materialam peterburgskikh arkhivov" [Archimandrite Antonin Kapustin and his academic activity. Based on materials from St. Petersburg archives]. In: Rukopisnoe nasledie russkikh vizantinistov v arkhivach SanktPeterburga [Manuscript heritage of Russian Byzantinists in the archives of St. Petersburg]. St. Petersburg, 1999, pp. 8-35 (in Russian).

Gessen, Vladimir. $K$ istorii ievreev: 300 let $v$ Sankt-Peterburge [Towards the history of the Jews: 300 years in St. Petersburg]. St. Petersburg, 2005 (in Russian).

Günzburg, David and Stassof, Vladimir. L'Ornement Hébraïque. Berlin, 1905 (in French).

Harkavy, Abraham and Strack, Hermann Leberecht. Catalog der Hebräischen Bibelhandschriften der Kaiserlichen Offentlichen Bibliothek in St. Petersburg. Erster und Zweiter Theil. St. Petersburg, Leipzig, 1875 (in German).

Iakerson, Semen. Ievreiskie sokrovishcha Peterburga. Svitki, kodeksy, dokumenty [Jewish Treasures of Petersburg. Scrolls, codices, documents]. St. Petersburg, 2008 (in Russian).

Ivask, Udo. Opisanie russkikh knizhnikh znakov. Ex-libris [Description of Russian book marks. Ex-libris]. Moscow, 1905 (in Russian).

Katsh, Abraham. "The Antonin Genizah in the Saltykov-Schedrin Public Library in Leningrad". In: The Leo Jung Jubilee Volume. Essays in his honor on the occasion of his seventieth birthday. Ed. by Menahem M. Kasher. New York, 1962, pp. 115-131 (in English).

Katsh, Abraham. "The Friedliana Library in the Leningrad Institute of Asiatic People". Perakim (Organ of the American Hebrew Academy), vol. III (1963), pp. 1-23 (in Hebrew).

Lisitsina, Alina. "Rukopisi iz kollektsii Gintsburgov v Rossiiskoi gosudarstvennoi biblioteke" [Manuscripts from the Günzburg collection in the Russian State Library]. Otechestvennye archivy [Domestic archives], no. 3, 2010, pp. 38-44 (in Russian).

Lisovoi, Nikolai. "Arkhimandrit Antonin Kapustin — issledovatel' sinaiskikh rukopisei (po stranitsam dnevnika)" [Archimandrite Antonin Kapustin — researcher of the Sinai manuscripts (Through the pages of the diary)]. In: Tserkov' $v$ istorii Rossii [The Church in the history of Russia]. Collection 4. Moscow, 2000, pp. 197-207 (in Russian).

Vereshchagin, Vasilii. Russkii knizhnyi znak [Russian book mark]. St. Petersburg, 1902 (in Russian).

Vikhnovich, Vsevolod. Karaim Avraam Firkovich. Ievreiskie rukopisi. Istoriia. Puteshestviia. [The Karaite Abraham Firkovich. Jewish Manuscripts. History. Journeys]. St. Petersburg, 2012 (in Russian). 
Wiener, Samuel. Bibliotheca Friedlandiana. Catalogus Librorum Impressorum Hebraeorum in Museo Asiatico Imperialis Academiae Scientiarum Petropolitanae asservatorum. Fasc. I-VI. Petropoli, 1893-1918 (in Russian).

\section{Who Was Collecting Hebrew Books in the Capital of Russian Empire and Why}

(Pis'mennye pamiatniki Vostoka, 2021, volume 18, no. 1 (issue 44), pp. 74-83) Received 18.10.2020.

Shimon M. Iakerson

Institute of Oriental Manuscripts, Russian Academy of Sciences; Dvortsovaia naberezhnaia 18, St. Petersburg, 191186 Russian Federation.

By the beginning of the 20th century, a unique collection of Hebrew manuscripts (more than 20,000 units) and first printed books was formed in the capital of the Russian Empire. These books ended up in St. Petersburg as part of several private collections, such as the collection of a Protestant paleographer and Biblical scholar Konstantin von Tischendorf, of the Karaite leader Avraam Firkovich, of the Archimandrite Antonin Kapustin, of the Barons Günzburg, of a First Guild merchant Moses Aryeh Leib Friedland and of an Orientalist Professor Daniel Chwolson. The history of these collections and the motives for the collecting activity of their owners are the subject of this article.

Key words: Hebrew manuscripts, Hebrew incunabula, Russian National Library, Russian State Library, Institute of Oriental Manuscripts, RAS, Konstantin von Tischendorf, Avraam Firkovich, Archimandrite Antonin, David Günzburg, Daniel Chwolson, Moses Friedland.

About the author:

Shimon M. Iakerson, Dr. Sci. (History), Leading Researcher of the Department of Middle Eastern and Near Eastern Studies, IOM RAS (shiakerson@yandex.ru). 